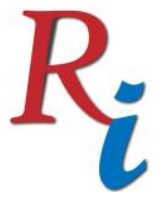

Asia Proceedings of Social Sciences

(APSS)

www.readersinsight.net/APSS

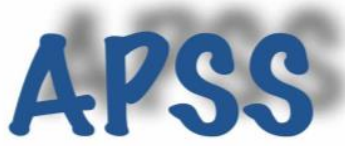

\title{
IMPACT OF SOCIAL FACTORS ON INDIVIDUAL TAX \\ COMPLIANCE
}

\section{Muthaloo Subramaniam*}

Faculty of Business, Accounting and Management

SEGi University

Malaysia

\section{Yamunah Vaicondam}

Faculty of Business, Accounting and Management

SEGi University

Malaysia

\section{Dineswary Nadarajan}

Faculty of Business, Accounting and Management

SEGi University

Malaysia

*Corrosponding author's Email: muthaloo@segi.edu.my

Author's Biography

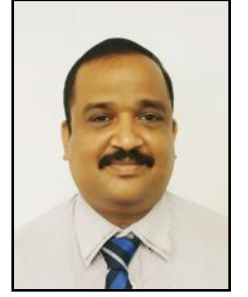

Mr. Muthaloo Subramaniam is currently a Senior Lecturer at the Faculty of Business, Accountancy and Management (FOBAM) at SEGi University, Malaysia. He is a well experienced accounting, IT and business professional with over 19 years of experience in the corporate and higher education. In addition, he also a Certified PSMB Trainer who holds a Certificate IV in Training and Assessment from. In a professional attachment, he is an Associate Member of Malaysian Institute of Accountants, Associate Member of Chartered Tax Institute of Malaysia, Member of Malaysian Institute of Management and Life Member of Malaysian Human Resource Management.

Peer-review under responsibility of $3^{\text {rd }}$ Asia International Multidisciplanry Conference 2019 editorial board (http://www.utm.my/asia/our-team/) (C) 2019 Published by Readers Insight Publisher, lat 306 Savoy Residencia, Block 3 F11/1,44000 Islamabad. Pakistan, info@ readersinsight.net This is an open access article under the CC BY-NC-ND license (http://creativecommons.org/licenses/by-nc-nd/4.0/). 


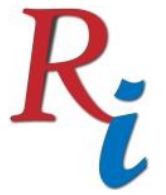

Asia Proceedings of Social Sciences

(APSS)

www.readersinsight.net/APSS

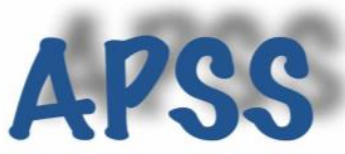

\section{Rese a r ch H i g h I igh t s}

Tax revenue is one of important government's sources of revenue and the taxation system vary across countries. Malaysia went through the paradigm shift by employing the self-assessment system (SAS) on 2001 where responsibility of calculating taxes had shifted successfully from the Inland Revenue Board of Malaysia (IRBM) to taxpayers. Since then, the voluntary tax compliance through SAS in Malaysia has been paying a greater role in meeting the statutory tax obligations and collection, effectively and efficiently. The study is aimed to examine the ethical, moral, religious and cultural background considerations on individual voluntary tax compliance in Malaysia by engaging quantitative research approach by utilising 200 valid questionnaire from respondents who are the individual taxpayer in Malaysia. Multiple regression analysis conducted to identify the effect of ethicality, morality, religiosity and cultural background on the individual voluntary tax compliance in Malaysia. Findings shows that all the variables have significant positive relationship, however the multiple regression analysis proven that ethicality and religiosity have strong significant effect on the individual tax compliance behaviour and on the other hand, morality and cultural background doesn't have significant effect on individual tax compliance behaviour.

\section{Research Objectives}

Researches have carried out numerous studies of the common factors which influences an individual tax compliance which are tax awareness (Kamaluddin \& Madi, 2005; Choong \& Edward Wong, 2011), tax fairness (Saad, 2014; Palil \& Mustapha, 2011), and perception of government (Tan, Mohd Salleh \& Md Kassim, 2017). Studies on tax compliance behaviour have been done is well developed countries and not in developing countries however the sociology factors that affects the income tax compliance in Malaysia is still lacking. This study may prove how the social norms of the people in Malaysia behave and their attitudes or personalities towards tax compliance. Therefore, the need to research and grow in the tax behaviour area is highly crucial. Hence this study is significant contributes in enlightening the tax payers, tax agents or the government on the factors that influence tax compliance activity. Thus, the purpose of this study is to identify sociology effect of the individuals in Malaysia on self-assessment system compliance by engaging the ethical, moral, religious and cultural in Malaysia. This study focused on Klang Valley due to the city being a good economic development area (Hway-Boon, Ong \& Shay, 2017). The respondents are the individual tax payers who are residing in the area of Klang Valley.

\section{Methodology}

Questionnaires are employed for data collection in this quantitative study. The first section of the questionnaire in the primary segment is to inspect the profile of respondents. The second part of the questionnaire focus on estimation to test tax compliance among the citizens. The elements that need to quantify in second segment comprise ethnicity, religiosity, tax morale and cultural background .The ideas in this survey are measured by the five scale from (1) "Strongly disagree" to (5) "Strongly agree ". Total 230 questionnaires distributed to respondents and $87 \%$ of the questionnaires returned with total no of 200 responses.

\section{Results}

Based on data collected for the questionnaires, the data has been conducted accordingly and analysed by engaging Statistical Package for the Social Science (SPSS) Version 22 package. 


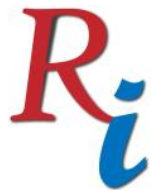

\section{Asia Proceedings of Social Sciences (APSS) \\ www.readersinsight.net/APSS}

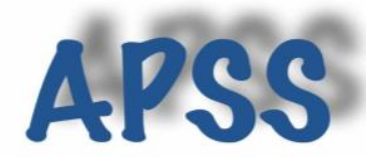

The reliability test shows that all 5 variables which consists of 29 items in total, have a Cronbach's Alpha of more than 0.7, which meant all the items in the questionnaire are acceptable and reliable. The ShapiroWilk test defined that data are normal and the P-Plot shows that dataset linear and fit for further analysis. The person correlation analysis shows significant positive relationship among all the variables. Therefore, the hypotheses are supported. The finding is further justified by Daniel Ho and Brossa Wong (2008) and Palil, M et.al (2011). Futhermore, the multiple regression analysis shows that ethicality and religiosity have strong significant effect on the individual tax compliance behaviour. On the other hand, morality and cultural background doesn't have significant effect on individual tax compliance behaviour.

\section{Findings}

The results revealed that not all of the proposed factors seem to influence individual taxpayers in Malaysia regarding their individual tax compliance. Ethicality, morality, religiosity and cultural background indicated a significant relationship with individual tax compliance. Both ethicality and religiosity showed a significant positive correlation with individual tax compliance. The results, however, revealed that there is no significant relationship between morality and cultural background. Besides that, the socio-economic background of taxpayers such as gender, age and educational qualification has significant influence on individual tax compliance in Malaysia.

\section{References}

Kamaluddin, A. and Madi, N. (2005),"Tax Literacy and Tax Awareness of Salaried Individuals in Sabah and Sarawak", Journal of Financial Reporting and Accounting, Vol. 3 Iss 1 pp. 71 - 89.

Palil, M. R., \& Mustapha, A. F. (2011). Determinants of tax compliance in Asia: A case of Malaysia. European Journal of Social Sciences, 24(1), 7-32.

Hway-Boon, Ong \& Shay, (2017). "Urban lifestyle in the Klang Valley", International Journal of Social Economics, https://doi.org/10.1108/IJSE-05-2016-0131

Choong, F. K., \& Edward Wong S. K. (2011). A Study on Self-Assessment Tax System Awareness in Malaysia. Australian Journal of Basic and Applied Sciences, 5(7), 881-888. Retrieved January 17 , 2019 , from https://www.researchgate.net/publication/265948055_A_Study_on_SelfAssessment_Tax_System_Awareness_in_Malaysia.

Saad, N. (2014). Tax Knowledge, Tax Complexity and Tax Compliance: Taxpayers' View. Procedia Social and Behavioral Sciences, 109, 1069-1075. Retrieved January 16, 2019, from https://www.sciencedirect.com/science/article/pii/S1877042813052294.

Tan, S. K., Mohd Salleh, M., \& Md Kassim, A. A. (2017). The Determinants of Individual Taxpayers' Tax Compliance Behaviour in Peninsular Malaysia. International Business and Accounting Research Journal, 1(1), 26-43. Retrieved January 16, 2019, from http://ibarj.com/index.php/ibarj/article/view/4

Daniel Ho and Brossa Wong, (2008),"Issues on compliance and ethics in taxation: what do we know?", Journal of Financial Crime, Vol. 15 Iss 4 pp. 369 - 382 